$\begin{array}{r}\text { Volume and Issues Obtainable at Center for Sustainability Research and Consultancy } \\ \text { Journal of Business and Social Review in Emerging Economies } \\ \text { ISSN: 2519-089X (E): 2519-0326 } \\ \text { Volume 6: No. 4, December } 2020 \\ \text { JSRC } \\ \text { Journal homepage: www.publishing.globalcsrc.org/jbsee } \\ \hline\end{array}$

\title{
The Impact of Covid- 19 Pandemic on Mental Well- Being of Health Care Workers: A Multi-Centre Study
}

\author{
${ }^{1}$ Nabila Hassan, ${ }^{2}$ Hina Akmal Memon, ${ }^{3}$ Noreen Hassan, ${ }^{4}$ Shobha Luxmi, ${ }^{5}$ Farhat Sultana \\ ${ }^{1}$ Assistant Professor, OBGYN, Liaquat University of Medical and Health Sciences (LUMHS), \\ Jamshoro, Pakistan, hassannabila310@ gmail.com \\ ${ }^{2}$ Women Medical Officer, OBGYN, Liaquat University of Medical and Health Sciences, (LUMHS), \\ Jamshoro, Pakistan, hinmemon@gmail.com \\ ${ }^{3}$ Lecturer, Business Administration, Federal Urdu University of Arts and Technology, (FUUAST) \\ Karachi, Pakistan, n.hassan@ fuuast.edu.pk \\ ${ }^{4}$ Assistant Professor, Infectious disease, Dow University of Health Sciences, Karachi, Pakistan, \\ shaobha.luxmi@duhs.edu.pk \\ ${ }^{5}$ Assistant Professor, OBGYN, Liaquat University of Medical and Health Sciences (LUMHS), \\ Jamshoro, Pakistan, farhatsaleem64@gmail.com
}

\begin{tabular}{l}
\hline ARTICLEDETAILS \\
\hline History \\
Revised format: November \\
2020 \\
Available Online: December \\
2020
\end{tabular}

Keywords

Mental Well- Being, COVID19, Fear of being infected, Anxiety

\section{JEL Classification}

II, I3

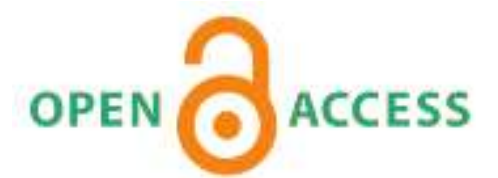

ABSTRACT

The study determines the effect of fear of being infected on anxiety and influence of anxiety on the disturbance of their mental well-being and to analyze the indirect effect of anxiety between fear of being infected and mental well-being. Cross-Sectional study carried out in the month of July 2020, by conducting a survey from health care workers (Doctors, Nurses and Trainees) covering hospitals from the region of Hyderabad, Jamshoro and Karachi. Analysis of the data done using two-step method of Structural Equation Model (SEM) approach. The findings of the study supported the positive and negative relationship fear of being infected to anxiety and anxiety to mental wellbeing respectively. In addition, the indirect relationship of anxiety also supported. Numerous unanswered queries pertinent to COVID-19 pandemic, and dubious situation leads towards huge size of disturbance in the lives of health care workers across the globe, therefore literature entails the necessity for researchers to study various factors that could have influence on mental well-being of an individual. The majority of relevant literature focused on mental well-being is from China, Europe, USA and other developed countries, however, fewer studies focused on South Asian region in general, and Pakistan in particular. So, present study fills the gap to unearth the factors of well-being for Pakistani health care workers. Pakistan have so far lost the lives of 58 healthcare providers to COVID-19 in the country and still counting while 240 healthcare providers are hospitalized. So there is intense need to study effect of mental well-being on health care workers as there is a need to save the survivors.

C2020 Center for Sustainability Research and Consultancy Pakistan under a Creative Commons Attribution-Non Commercial-Share Alike 4.0 
Corresponding author's email address: n.hassan@fuuast.edu.pk

Recommended citation: Hassan, N., Memon, H. K., Hassan, N., Luxmi, S. \& Sultana, F. (2020). The impact of Covid- 19 Pandemic on Mental Well- Being of Health Care Workers: A Multi-Centre Study. Journal of Business and Social Review in Emerging Economies, 6(4), 1313-1322.

\section{Introduction}

Human history corroborates that an outburst of any pandemic results in multiple human causalities, a large number of suspected patients, the wave of uncertainty and deep down fear. The outbreaks of infectious diseases have been greater threat on human health and wellbeing since ages (Duncan, Schaller, \& Park, 2009). The emergence of a novel type of corona virus, named as COVID-19, initially from Wuhan, China in December 2019 later on involving almost the whole world evoked immense challenges. This sheer speed of both the land extension and the unexpected increment in quantities of cases astonished and immediately overpowered health and public health services(Wu \& McGoogan, 2020).

COVID-19 caused by a beta coronavirus named SARS-CoV-2 that affects the lower respiratory tract (Sohrabi et al., 2020) transmitted through respiratory droplets taking equal time for incubation and generation as SARS Corona virus (Wilson \& Chen, 2020). On 22 of February year 2020, World Health Organization (WHO) confirmed COVID-19, a Public Health Emergency of International Concern and afterward it declared as Pandemic and By July 23, 2020, globally more than 200 counties/regions have reported rising toll of infection, morbidity and mortality.

Situation in Pakistan is alarming as well as number of active cases has surged to more than 400 million cases with more than 8000 fatalities (Waris, Khan, Ali, Ali, \& Baset, 2020). As this pandemic was new, many of the health workers were not ready for it (Haq, Shafiq, \& Sheikh, 2020).Globally the Healthcare workers(HCWs) are facing different problems related to their physical health, mental health and safety (Li, Song, Wong, \& Cui, 2020). It is true for Pakistan where economic problems, limited facilities and infrastructure, with lack access to personal protective equipment (PPEs) and proper training such as donning and doffing pose the health care workers at greater risk being infected. (Haq et al., 2020).

As a result, many healthcare workers are contracting infection and some others who remain in contact with those positive cases are going to self-quarantine creating pressure in hospital and tertiary care units. An initial report revealed, as many as 765 healthcare workers including doctors (440), nurses (111) and paramedics (215) have tested positive for COVID 19 up till june 2020. (Harris, Bhatti, Buckley, \& Sharma, 2020). There are also reports that healthcare workers once contracting disease are also infecting other healthy patients. Situation becomes worse when news of deaths of healthcare workers due to COVID 19 reported. This led to nervousness and anxiety for health care workers while examining their patients with positive COVID 19, resulting in severe mental disturbance (Satici, Saricali, Satici, \& Griffiths, 2020). This reflects that "The flare-up of Corona Virus illness 2019 (COVID-19) might be upsetting. Dread and nervousness, fear and anxiety about a disease can be overpowering for health care workers". (CDC-Report) Notably, research endeavors concerning COVID-19 pandemic needed to create proof driven methodologies to diminish unfavorable mental effects and mental indications (P. Li et al., 2020).

The development of COVID-19 pandemic might prompt psychological trouble, nervousness and fear may lead to harmful stereotypes (Bangalore et al., 2020). Hence, it is important to pay adequate attention towards the mental wellbeing of health care workers through actualizing ways to encourage it at numerous degrees of experience during this unprecedented time of COVID-19 pandemic (Huang et al., 2020). Overall, experts around the globe are emphasizing on uplifting the mental wellbeing of public suffered by rising magnitude and intensity of COVID-19 pandemic (Chen et al., 2020; Rajkumar, 2020) but there is a dire need to uplift the mental well-being of health care workers who are actually dealing with the patients. This pandemic situation worldwide is representing a genuine threat to wellbeing due to fear of being infected, economic downturn and unavailability of clinically affirmed vaccines or specific therapeutic medications accessible for COVID-19. 
This scenario poses numerous unanswered queries pertinent to COVID-19 pandemic, and consequently, the dubious situation leads towards huge size of disturbance in the lives of Health care workers across the globe, which entails the necessity for researchers to study various factors that could have influence on mental wellbeing of an individual (Chen et al., 2020)

The contribution of this research towards relevant literature is twofold. Firstly, this study is first attempt to examine the underlying relationship between fear, anxiety and mental wellbeing in a single study in the context of COVID-19 Pandemic. Secondly, majority of relevant literature focused on China, Europe, USA and other developed countries, however, fewer studies focused on South Asian region in general, and Pakistan in particular.

Fear of being infected reflects people general tendency to perceive themselves vulnerable to infections and risk of being contaminated with viruses (Stürmer, Rohmann, Mazziotta, Siem, \& Barbarino, 2017) suggested as Fear is an adaptive response in the presence of danger. However, when threat is uncertain and continuous, as in the current coronavirus disease (COVID-19) pandemic, fear can become chronic and burdensome. Chinese study finding indicates confronted with the COVID-19 epidemic, HCWs including doctors and frontline workers feel very anxious about getting infected and had a great psychological distress and anxiety. The nurses were more conscious about being infected at work than doctors, technicians and support personnel, which cause the sky-high level of anxiety, excessive fatigue, depressions and tensions. As a result quality of work found seriously affected. Moreover, the study sturdily marked the acute level of distress and anxiety because of the fear of being infected apparently it seems that there are no significant difference in mental condition between HCWs with or without self-infection (Dai, Hu, Xiong, Qiu, \& Yuan, 2020). Another study on Thai discovered same psychological impacts over mental health and work performance. Surprisingly most HCWs found overawed by a frightening nightmare to them, depression, lack of attentiveness and greater anxiety. These emotions proved somehow good, as they lead towards more appropriate infection prevention practices but still number of HCWs were not willing and were not satisfied to accept new patients infected by COVID-19 or to see them admitted. However, the most crucial part is that the HCWs are found vague for not giving reasonable attend towards their tasks and not putting their required concentration at their work, raising issues on patient's safety and health.(Anucha Apisarnthanarak et al., 2020). (Jungmann \& Witthöft, 2020) emphasized specifically on analyzing the factors related to anxiety and the similar relationship where COVID-19 pandemic sit for adverse behaviors. The existing situation of coronavirus (SARS-CoV-2) pandemic is becoming the reason of mental and physical anxiety and high fatality with major impact on quality of life. Therefore, on the ground of the preceding studies, it is hypothesized that:

\section{H1: Fear of being infected positively related to Anxiety}

World Health Organization define mental well-being as an ability to live, work and appreciate diversion in a network where one has a feeling of belongingness and support, and the capacity to make meaningful contributions. The study of (Roy et al., 2020)expressed the effect of massive anxiety during pandemic situation specifically on Indian population, reported the massive reaction by people of all domains. This situation was determined from the time when media was broadcasting constantly through borders to possess every one up-to-date about the pandemic situation, which affect mental health due to anxiety, depression, fatigue and distress. . A Study from China by (Ahmed et al., 2020) indicates that anxiety remains negatively associated with mental wellbeing. Lock down and self-isolation significantly raised mental health problem with hazardous and harmful alcohol use. The study further added that the youngsters showed lowest mental well-being and provided psychiatric treatment to improve the wellbeing. Another study on health care workers and frontline staff highlighted that as COVID-19 pandemic is generating a massive health care problem that can reflect in different ways affecting their mental wellbeing as depression anxiety leads towards excessive sensation of aloneness, injurious liquor and drug use, self-harm or suicidal activities (Zaka, Shamloo, Fiorente, \& Tafuri, 2020).

\section{H2: Anxiety negatively related to mental well-being}

Corona virus is affecting the life of the people overall. It makes a feeling of fear and lead to stress, 
nervousness and ultimately to mental issues. As indicated by Center for Disease Control and Prevention (CDC) Fear and anxiety about a disease can be overpowering. Another study by (Desclaux, Diop, \& Doyon, 2017), (Jeong et al., 2016)found the participants having fears about their own health or fears of infecting others including their family members. They likewise turned out stressed in the event that they encountered any physical symptoms conceivably identified with the disease and fear that the symptoms could reflect having the infection kept on recognized with mental results. The study of (Evanoff et al., 2020) deliberated professional and private issues linked with psychological comfort and acknowledged stress, anxiety, depression, work-exhaustion, burnout, and reduced comfort between faculty and staff at a university and academic medical center during the SARS-CoV-2 pandemic. The frequency of unease, melancholy, and work exhaustion slightly advanced amongst clinicians than non-clinicians. Between all employees, anxiety, depression, and high work fatigue autonomously related with community or clinical exposure to COVID-19 fear of infection. Additionally, age below 40 and a vast number of family or home with stress also allocated with just handful outcomes. The study suggests that the mental wellbeing and health negatively affected of clinical and non-clinical staff during this pandemic situation due to depression and anxiety created.

\section{H3: Anxiety negatively mediates the relationship between Fear of being infected and mental well- being}

Figure- 1 demonstrate the conceptual framework of the present study

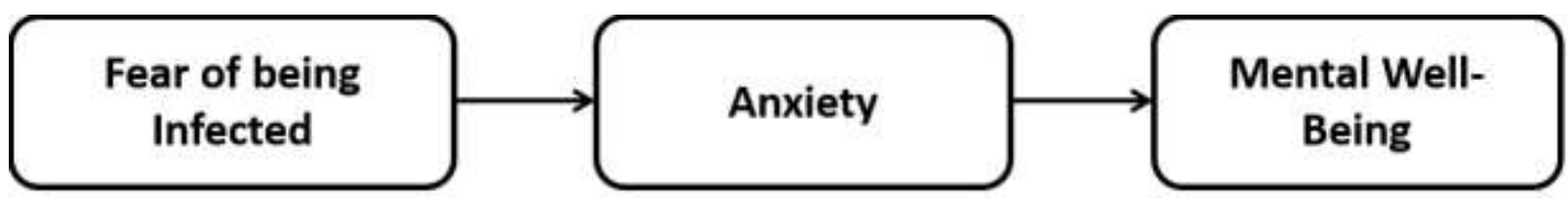

Source: Researcher

Figure-1 Model of the study

\section{Methods and Methods}

The present study carried out with Cross-Sectional Research Design whereby the data collected over the month of July 2020 by conducting a survey from health care workers (Doctors, Nurses and Trainees) covering 12 hospitals from the region of Hyderabad, Jamshoro and Karachi. The primary data collected using convenience non-random sampling technique. For this study the ethical standards were strictly considered while performing procedures in studies comprised of human participants. The 7-item scale of fear of being infected" adapted from the work of (Ahorsu et al., 2020). 5-item scale of Anxiety adopted from the work of (Lee, 2020). 14-item scale of Mental Well-Being adopted from the work of WarwickEdinburgh (2007) (Tennant et al.). For testing the significance and relevance of path coefficients, partial least square (PLS-SEM) approach employed using SMART PLS 3.0 (Henseler, Ringle, \& Sarstedt, 2015).

Table -1 indicate the demographic details of the present study

Table 1: Demographic Details

\begin{tabular}{lcc}
\hline \multicolumn{3}{c}{ GENDER } \\
\hline Male & Frequency & Percent \\
Female & 119 & 31.81 \\
Total & 255 & 68.18 \\
\hline \multicolumn{3}{c}{ AGE } \\
\hline \multicolumn{3}{c}{ Frequency } \\
\hline Less than 28 & 374 & Percent \\
28- 35 & 54 & 14.43 \\
36-43 & 120 & 32.08 \\
Above 43 & 145 & 38.77 \\
Total & 55 & 14.72 \\
\hline \multicolumn{3}{c}{374} \\
\hline
\end{tabular}




\begin{tabular}{|c|c|c|}
\hline & Frequency & Percent \\
\hline Civil Hospital & 40 & 10.69 \\
\hline Agha Khan Hospital & 26 & 06.96 \\
\hline St. Elizabeth & 32 & 08.56 \\
\hline Sindh Government & 30 & 08.03 \\
\hline Isra Hospital & 26 & 06.95 \\
\hline Lady Dufferin Hospital & 19 & 05.08 \\
\hline MaaJee Hospital & 26 & 06.95 \\
\hline $\begin{array}{l}\text { Dow University of health } \\
\text { sciences Karachi }\end{array}$ & 37 & 09.89 \\
\hline Red Crescent Hospital & 34 & 09.09 \\
\hline $\begin{array}{l}\text { Liaquat University Hospital, } \\
\text { Jamshoro }\end{array}$ & 31 & 08.29 \\
\hline Sehat & 34 & 09.09 \\
\hline City Care Hospital & 39 & 10.42 \\
\hline Total & 374 & 100.0 \\
\hline \multicolumn{3}{|c|}{ DESIGNATION } \\
\hline & Frequency & Percent \\
\hline Doctor & 154 & 0 \\
\hline Nurse & 122 & 0 \\
\hline Trainee & 98 & 0 \\
\hline Total & 374 & 100.0 \\
\hline
\end{tabular}

Source: Researcher

\section{Results}

As the table-2 indicated, the outer loadings and Composite Reliability more than satisfactory as all the values are higher than 0.50 establishing indicator reliability (F. Hair Jr, Sarstedt, Hopkins, \& G. Kuppelwieser, 2014) and 0.70 establishing internal consistency reliability (Hair, Black, Babin, Anderson, \& Tatham, 2006) respectively. The average variance extracted values for all constructs are greater than 0.5 (Hair et al., 2006) and hence establishes the convergent validity.

Table 2: Reliability and Validity

\begin{tabular}{|c|c|c|c|c|}
\hline CONSTRUCT & ITEMS & $\begin{array}{c}\text { OUTER } \\
\text { LOADINGS } \\
\end{array}$ & $\begin{array}{l}\text { COMPOSITE } \\
\text { RELIABILITY } \\
\end{array}$ & $\begin{array}{c}\text { AVERAGE VARIANCE } \\
\text { EXTRACTED } \\
\end{array}$ \\
\hline \multirow{5}{*}{ Anxiety } & ANX1 & 0.767 & \multirow{5}{*}{0.912} & \multirow{5}{*}{0.674} \\
\hline & ANX2 & 0.845 & & \\
\hline & ANX3 & 0.793 & & \\
\hline & ANX4 & 0.860 & & \\
\hline & ANX5 & 0.836 & & \\
\hline \multirow{6}{*}{$\begin{array}{l}\text { Fear of being } \\
\text { infected }\end{array}$} & FOI1 & 0.745 & \multirow{6}{*}{0.850} & \multirow{6}{*}{0.889} \\
\hline & FOI2 & 0.752 & & \\
\hline & FOI3 & 0.662 & & \\
\hline & FOI4 & 0.787 & & \\
\hline & FOI5 & 0.750 & & \\
\hline & FOI6 & 0.830 & & \\
\hline \multirow{9}{*}{$\begin{array}{c}\text { Mental } \\
\text { well being }\end{array}$} & MWB1 & 0.670 & \multirow{9}{*}{0.925} & \multirow{9}{*}{0.934} \\
\hline & MWB10 & 0.720 & & \\
\hline & MWB11 & 0.633 & & \\
\hline & MWB12 & 0.613 & & \\
\hline & MWB13 & 0.727 & & \\
\hline & MWB14 & 0.757 & & \\
\hline & MWB2 & 0.710 & & \\
\hline & MWB3 & 0.691 & & \\
\hline & MWB4 & 0.699 & & \\
\hline
\end{tabular}




\begin{tabular}{ll}
\hline MWB5 & 0.749 \\
MWB6 & 0.743 \\
MWB7 & 0.788 \\
MWB8 & 0.718 \\
MWB9 & 0.704 \\
\hline
\end{tabular}

Source: Researcher

Illustrated in figure-2 the measurement model (representing outer loading and beta coefficient) on SMART PLS software.

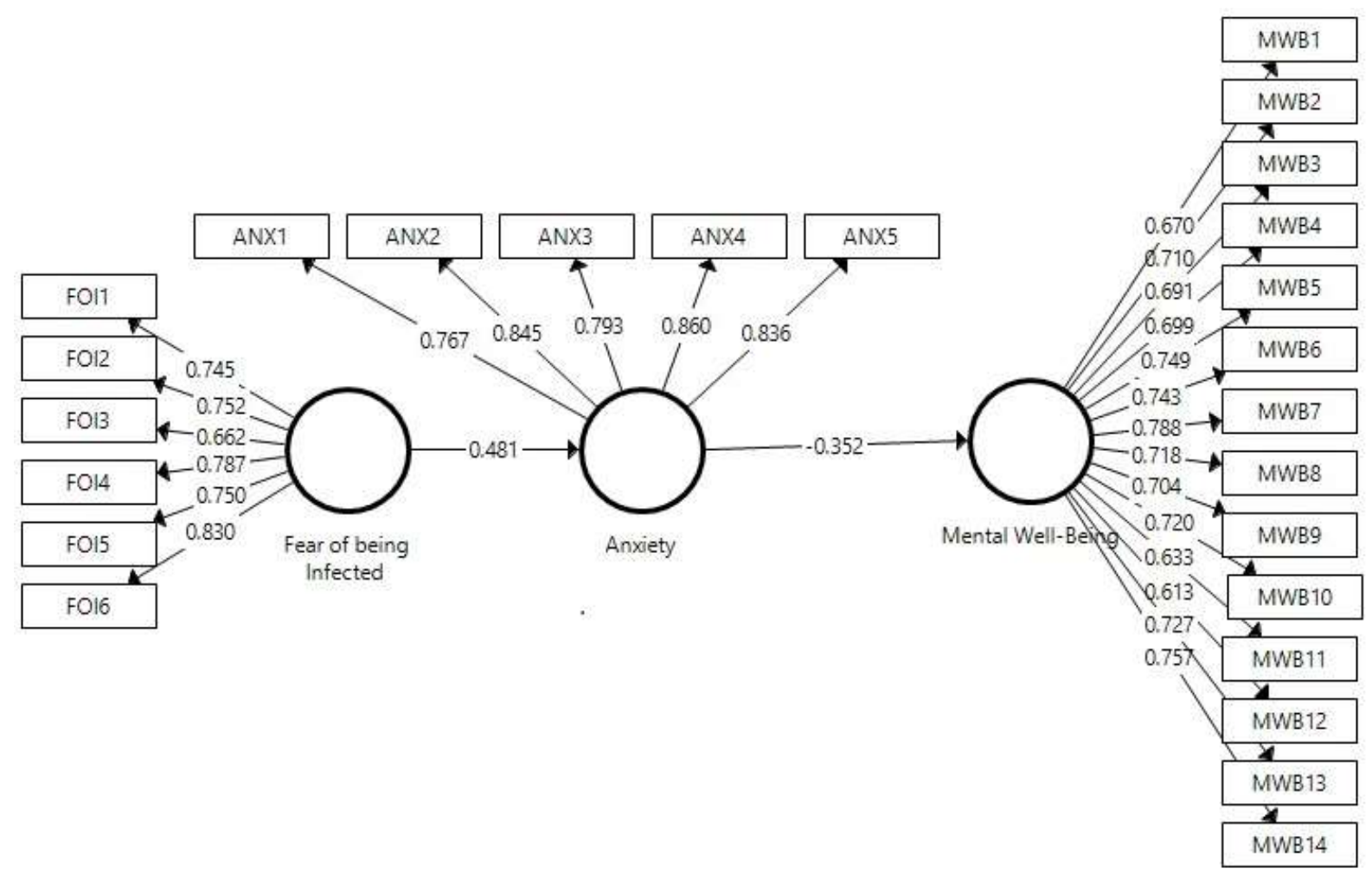

Source: Researcher

Figure-2 Outer Model (Smart PLS)

As specified in table -3 all the HTMT values are below 0.85 (Henseler et al., 2015) ascertained discriminant validity

Source: Researcher

Table 3 Discriminant validity

\begin{tabular}{lccc}
\hline & 1 & 2 & 3 \\
\hline Anxiety & & & \\
Fear of being Infected & 0.546 & & \\
Mental Well-Being & 0.366 & 0.119 & \\
\hline
\end{tabular}

In the study the bootstrapping method with 5000 re samples (Hair, Hult, Ringle, \& Sarstedt, 2017) via Bias-Corrected and Accelerated (BCA) Bootstrap with one tailed test where significance level is 0.05 employed . 
Table 4: Significance \& Relevance of Path Coefficients

\begin{tabular}{lcccccc}
\hline & Original & & & & \\
& Sample & $($ STDEV $)$ & $\mid$ O/STDEV $\mid$ & P Values & $5.00 \%$ & $95.00 \%$ \\
\hline Fear of being Infected $\rightarrow$ Anxiety & 0.481 & 0.054 & 8.955 & 0.000 & 0.387 & 0.563 \\
Anxiety $\rightarrow$ Mental Well-Being & -0.352 & 0.062 & 5.701 & 0.000 & -0.443 & -0.237 \\
Fear of being Infected $\rightarrow$ Anxiety $\rightarrow$ Mental Well-Being & -0.169 & 0.031 & 5.516 & 0.000 & -0.221 & -0.12 \\
\hline
\end{tabular}

\section{Source: Researcher}

Table- 4 specifies that fear of being infected is positively and significantly associated to anxiety and anxiety of HCWs is negatively associated with mental wellbeing indicating increase in anxiety with reduce their mental well-being and significance presence of anxiety as a mediator between the relationship(F. Hair Jr et al., 2014; Preacher \& Hayes, 2008)

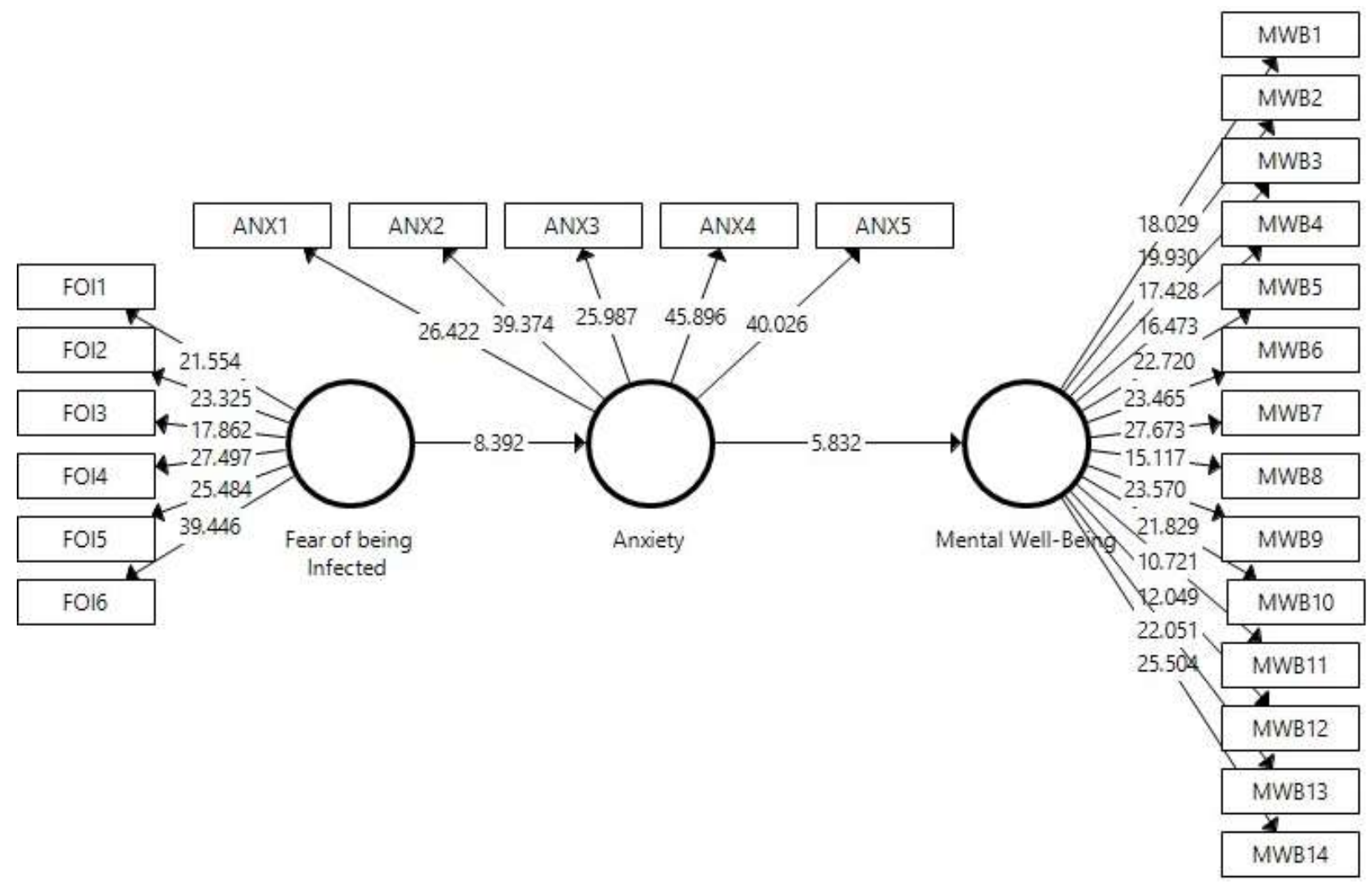

Figure-3 Inner Model (Smart PLS)

Source: Researcher

From figure-3 it is clear that present study model explains $49.2 \%$ of total variance in anxiety and $35.7 \%$ in mental wellbeing exhibited moderate level of R-square. Study indicates the predictive relevance of the model.

\section{Discussion}

This finding is in line with literature that there exist psychological impacts of COVID-19 pandemic outbreak on healthcare workers. As stated in a recent study (Dai et al., 2020) that corona virus anxiety was lowest when individuals use adaptive emotion regulation strategies (acceptance and putting into perspective). Due to this pandemic situation, health care workers have a great fear of being infected leading to depression, anxiety and excessive fatigue. As stated by (Anucha Apisarnthanarak et al., 2020) that "Although these emotions are proved to be good, as they lead towards more appropriate infection prevention practices but still number of HCWs were not willing and were not satisfied to accept new 
patients infected by COVID-19 or to see them admitted". It is evident that there are a high number of HCWs affected by various psychological ailments however the most crucial part is that the HCWs are found vague for not giving reasonable attend towards their tasks and not putting their required concentration at their work, that can raise issues of patient's safety and health.

The current study has found a negative relationship of anxiety and mental well-being. At the extent mental well-being expected to be improved by providing valuable supportive information related to selfquarantine and social distancing to overcome but this was not the case for health workers as they are continuously examining their patients with fear of being infected leading anxiety. They further confess sleeplessness and mental disturbance due to the resultant anxiety. A study on mental well-being identified that an indication of improvement in mental well-being showed peoples' willingness and positive response to follow governmental guidelines to cope up the difficult situation but an outcome in reality significantly affects mental health problem due to frustration, depression, anxiety and distress (Roy et al., 2020). Both the government and health care agencies are responsible for protecting the psychological well-being of health care communities all over the world and ensuring a healthy work environment. Since there is a high prevalence of psychological trauma consequences among HCWs due to this pandemic; it is imperative to invest resources to promote the mental health welfare of frontline professionals. Older participants experienced greater well-being and a lower level of stress compared to younger ones. Doctors reported more stress than trainee and nurses. Anxiety had a strong effect on the overall well-being of physicians. As it is stated (Zaka et al., 2020) that COVID 19 Pandemic creates mental illness, anxiety, depression, stress which reflect due to fear of being infected.

The current study has found a negative mediating relationship of anxiety between fear of being infected and mental well-being which is in line with literature. The HCW's found afraid of less precautionary measures used by the patients and this non co-operative attitude of patients found leading further into a high level of depression, exhaustion and fear for the HCWs. As stated by (A. Apisarnthanarak et al., 2020) the HCWs who are suffering from pandemic situation are fenced by a fear of being infected with suspected or confirmed COVID-19 patients, as they are absurdly exposed reported psychological distress. Furthermore, we find out that this crucial situation is making the anxiety stronger in HCWs, as in lined by (Jungmann \& Witthöft, 2020) that COVID 19 pandemic is becoming the reason of mental trauma. As an outcome panel(Ahmed et al., 2020)defined that this current situation significantly affects mental health problem like frustration, depression and distress.

\section{Conclusion}

Development and spread of COVID-19 prompt psychological trouble, nervousness, and fear so emphasizing on uplifting the mental wellbeing of health care workers. The findings of the study supported the positive and negative relationship fear of being infected - anxiety and anxiety - mental wellbeing respectively. This research has certain limitations; first, it is hard to measure hundred percent views of any health care workers. As the perception is the individual expression which in hidden as it inside view or state of mind of participant, this could be ascertain only through the responses attempted by individual in the pandemic situation. Further, the survey conducted considering certain geographical region that might reflect bias. The outcomes cannot be generalized so it is suggested for prospect scholars and researchers to include the other geographical sectors, with a larger population. Moreover the work can be broaden with additional moderating and mediating variables using other variables like emotional exhaustion, depression, mental illness, insomnia etc.

\section{References}

Ahmed, M. Z., Ahmed, O., Aibao, Z., Hanbin, S., Siyu, L., \& Ahmad, A. (2020). Epidemic of COVID19 in China and associated Psychological Problems. Asian journal of psychiatry, 102092.

Ahorsu, D. K., Lin, C.-Y., Imani, V., Saffari, M., Griffiths, M. D., \& Pakpour, A. H. (2020). The fear of COVID-19 scale: development and initial validation. International Journal of Mental Health and Addiction. doi:https://doi.org/10.1007/s11469-020-00270-8 
Apisarnthanarak, A., Apisarnthanarak, P., Siripraparat, C., Saengaram, P., Leeprechanon, N., \& Weber, D. J. (2020). Impact of Anxiety and Fear for COVID-19 Toward Infection Control Practices Among Thai Healthcare Workers. Infection Control \& Hospital Epidemiology, 1-6. doi:https://doi.org/10.1017/ice.2020.280

Apisarnthanarak, A., Apisarnthanarak, P., Siripraparat, C., Saengaram, P., Leeprechanon, N., \& Weber, D. J. (2020). Impact of anxiety and fear for COVID-19 toward infection control practices among Thai healthcare workers. Infect Control Hosp Epidemiol, 1-2. doi:10.1017/ice.2020.280

Bangalore, S., Sharma, A., Slotwiner, A., Yatskar, L., Harari, R., Shah, B., . . Alviar, C. L. (2020). STsegment elevation in patients with Covid-19-a case series. New England Journal of Medicine. doi:https://doi.org/10.1056/nejmc2009020

Chen, N., Zhou, M., Dong, X., Qu, J., Gong, F., Han, Y., . . . Wei, Y. (2020). Epidemiological and clinical characteristics of 99 cases of 2019 novel coronavirus pneumonia in Wuhan, China: a descriptive study. The lancet, 395(10223), 507-513. doi:https://doi.org/10.1016/S01406736(20)30211-7

Dai, Y., Hu, G., Xiong, H., Qiu, H., \& Yuan, X. (2020). Psychological impact of the coronavirus disease 2019 (COVID-19) outbreak on healthcare workers in China. MedRxiv. doi:https://doi.org/10.1101/2020.03.03.20030874

Desclaux, A., Diop, M., \& Doyon, S. (2017). Fear and Containment. The Politics of Fear: Médecins Sans Frontières and the West African Ebola Epidemic, 209-234.

Duncan, L. A., Schaller, M., \& Park, J. H. (2009). Perceived vulnerability to disease: Development and validation of a 15-item self-report instrument. Personality and Individual differences, 47(6), 541546. doi:https://doi.org/10.1016/j.paid.2009.05.001

Evanoff, B. A., Strickland, J. R., Dale, A. M., Hayibor, L., Page, E., Duncan, J. G., . . . Gray, D. L. (2020). Work-related and Personal Factors Associated with Mental Well-being during COVID19 Response: A Survey of Health Care and Other Workers. MedRxiv. doi:https://doi.org/10.1101/2020.06.09.20126722

F. Hair Jr, J., Sarstedt, M., Hopkins, L., \& G. Kuppelwieser, V. (2014). Partial least squares structural equation modeling (PLS-SEM) An emerging tool in business research. European Business Review, 26(2), 106-121. doi:https://doi.org/10.1108/EBR-10-2013-0128

Hair, J. F., Black, W. C., Babin, B. J., Anderson, R. E., \& Tatham, R. L. (2006). Multivariate data analysis (Vol. 6). In: Upper Saddle River, NJ: Pearson Prentice Hall.

Hair, J. F., Hult, G. T. M., Ringle, C. M., \& Sarstedt, M. (2017). A primer on partial least squares structural equation modeling (PLS-SEM) (Vol. null): Sage.

Haq, M. I. U., Shafiq, F., \& Sheikh, H. (2020). Potential Barriers Amongst Health Care Professionals (HCPs) of Pakistan in Managing COVID 19 patients. Pakistan Journal of Medical Sciences, 36(COVID19-S4). doi:https://doi.org/10.12669/pjms.36.COVID19-S4.2753

Harris, M., Bhatti, Y., Buckley, J., \& Sharma, D. (2020). Fast and frugal innovations in response to the COVID-19 pandemic. Nature Medicine, 1-4. doi:https://doi.org/10.1038/s41591-020-0889-1

Henseler, J., Ringle, C. M., \& Sarstedt, M. (2015). A new criterion for assessing discriminant validity in variance-based structural equation modeling. Journal of the academy of marketing science, 43(1), 115-135. doi:https://doi.org/10.1007/s11747-014-0403-8

Huang, C., Wang, Y., Li, X., Ren, L., Zhao, J., Hu, Y., . . . Gu, X. (2020). Clinical features of patients infected with 2019 novel coronavirus in Wuhan, China. The lancet, 395(10223), 497-506. doi:https://doi.org/10.1016/S0140-6736(20)30183-5

Jeong, H., Yim, H. W., Song, Y.-J., Ki, M., Min, J.-A., Cho, J., \& Chae, J.-H. (2016). Mental health status of people isolated due to Middle East Respiratory Syndrome. Epidemiology and health, 38. doi:https://doi.org/10.4178/epih.e2016048

Jungmann, S. M., \& Witthöft, M. (2020). Health anxiety, cyberchondria, and coping in the current COVID-19 pandemic: Which factors are related to coronavirus anxiety? Journal of Anxiety Disorders, 102239. doi:https://doi.org/10.1016/j.janxdis.2020.102239

Lee, S. A. (2020). Coronavirus Anxiety Scale: A brief mental health screener for COVID-19 related anxiety. Death studies, 44(7), 393-401. doi:https://doi.org/10.1080/07481187.2020.1748481 
Li, P., Fu, J.-B., Li, K.-F., Liu, J.-N., Wang, H.-L., Liu, L.-J., . . . Tang, A. (2020). Transmission of COVID-19 in the terminal stages of the incubation period: A familial cluster. International Journal of Infectious Diseases, 96, 452-453. doi:https://doi.org/10.1016/j.ijid.2020.03.027

Li, X., Song, Y., Wong, G., \& Cui, J. (2020). Bat origin of a new human coronavirus: there and back again. Science China Life Sciences, 63(3), 461-462. doi:https://doi.org/10.1007/s11427-020$1645-7$

Preacher, K. J., \& Hayes, A. F. (2008). Asymptotic and resampling strategies for assessing and comparing indirect effects in multiple mediator models. Behavior research methods, 40(3), 879891.

Rajkumar, R. P. (2020). COVID-19 and mental health: A review of the existing literature. Asian journal of psychiatry, 102066.

Roy, D., Tripathy, S., Kar, S. K., Sharma, N., Verma, S. K., \& Kaushal, V. (2020). Study of knowledge, attitude, anxiety \& perceived mental healthcare need in Indian population during COVID-19 pandemic. Asian journal of psychiatry, 102083. doi:https://doi.org/10.1016/j.ajp.2020.102083

Satici, B., Saricali, M., Satici, S. A., \& Griffiths, M. D. (2020). Intolerance of uncertainty and mental wellbeing: serial mediation by rumination and fear of COVID-19. International Journal of Mental Health and Addiction. doi:https://doi.org/10.1007/s11469-020-00305-0

Sohrabi, C., Alsafi, Z., O’Neill, N., Khan, M., Kerwan, A., Al-Jabir, A., . . . Agha, R. (2020). World Health Organization declares global emergency: A review of the 2019 novel coronavirus (COVID-19). International Journal of Surgery. doi:https://doi.org/10.1016/j.ijsu.2020.02.034

Stürmer, S., Rohmann, A., Mazziotta, A., Siem, B., \& Barbarino, M. L. (2017). Fear of infection or justification of social exclusion? The symbolic exploitation of the Ebola epidemic. Political Psychology, 38(3), 499-513. doi:https://doi.org/10.1111/pops.12354

Tennant, R., Hiller, L., Fishwick, R., Platt, S., Joseph, S., Weich, S., . . Secker, J. \& Stewart-Brown, S.(2007). The Warwick-Edinburgh mental well-being scale (WEMWBS): development and UK validation. Health and Quality of life Outcomes, 5(1), 63. doi:https://doi.org/10.1186/1477-7525$5-63$

Waris, A., Khan, A. U., Ali, M., Ali, A., \& Baset, A. (2020). COVID-19 outbreak: current scenario of Pakistan. New Microbes and New Infections, 100681. doi:https://doi.org/10.1016/j.nmni.2020.100681

Wilson, M. E., \& Chen, L. H. (2020). Travellers give wings to novel coronavirus (2019-nCoV). In: Oxford University Press.

Wu, Z., \& McGoogan, J. M. (2020). Characteristics of and important lessons from the coronavirus disease 2019 (COVID-19) outbreak in China: summary of a report of 72314 cases from the Chinese Center for Disease Control and Prevention. Jama, 323(13), 1239-1242. doi:https://doi.org/10.1001/jama.2020.2648

Zaka, A., Shamloo, S. E., Fiorente, P., \& Tafuri, A. (2020). COVID-19 pandemic as a watershed moment: A call for systematic psychological health care for frontline medical staff. doi:https://doi.org/10.1177\%2F1359105320925148 